\title{
PERBANDINGAN TINGKAT MOTIVASI MAHASISWA YANG MENEMPUH KULIAH KONVENSIONAL DENGAN COLLABORATIVE LEARNING
}

\author{
Herman*, Titi Savitri P**, Widyandana** \\ * Program Studi IImu Kesehatan Masyarakat, Fakultas Kedokteran dan Kesehatan, Universitas Tadulako \\ ** Bagian Pendidikan Kedokteran, Fakultas Kedokteran, Universitas Gadjah Mada
}

\begin{abstract}
Background: Collaborative learning is a learning method which centered on students' learning process. Although many theories and research results showed that interactive lecture is better than conventional lecture, but in fact, only few lecturers use the interactive method in teaching and learning process. Literature stated that using conventional method in teaching and learning process does not motivate students to learn more while using the other one (interactive lecture) will enhance students' motivation. Collaborative learning is one of interactive lecture method. Based on the facts mentioned above, the researcher wants to compare students' motivation who participate in conventional method and those who participate in collaborative learning method.

Method: This was a quantitative research with experimental approach, used post-test only with control group design. This research measured students' learning motivation by using Motivated Strategies for Learning Questionnaire (MSLQ). Subjects for the research were the second semester students of Public Health Science of Tadulako University which divided into two groups randomly. Data were analyzed by Mann-Whitney test method.

Results: There were a distinct disparity in students' learning motivation after following learning process with conventional and collaborative learning method. Students who followed collaborative learning had higher motivation than students who followed conventional lecture.

Conclusion: Collaborative learning improves students'learning motivation toward the nutrient topic on Public Health Sciences.
\end{abstract}

KEYWORDS: lecture, conventional lecture, collaborative learning, learning motivation

\section{ABSTRAK}

Latar belakang: Collaborative learning adalah metode belajar kelompok yang berpusat kepada mahasiswa pada proses pembelajarannya. Meskipun berdasar teori dan hasil-hasil penelitian terdahulu, kuliah interaktif terbukti lebih baik dari kuliah konvensional, namun pada kenyataannya dosen masih banyak menggunakan metode kuliah konvensional dalam proses pembelajaran. Hal ini menyebabkan berkurangnya motivasi mahasiswa dalam mengikuti proses pembelajaran. Kuliah dengan metode collaborative learning termasuk salah satu kuliah interaktif. Berdasar hal-hal tersebut di atas, maka penulis ingin mengetahui motivasi belajar mahasiswa yang menempuh kuliah metode konvensional dibandingkan dengan metode collaborative learning.

Metode: Penelitian kuantitatif dengan metode eksperimen, dan rancangan post-test only with control group. Penelitian ini menilai motivasi belajar mahasiswa yang diukur dengan Motivated Strategies for Learning Questionnaire (MSLQ). Subjek Penelitian adalah seluruh mahasiswa Ilmu Kesehatan Masyarakat angkatan 2011 semester dua. Mahasiswa dikelompokkan menjadi dua kelompok secara acak. Data dianalisis dengan menggunakan uji Mann-Whitney.

Hasil: Ada perbedaan bermakna motivasi belajar mahasiswa setelah mengikuti proses belajar dengan metode konvensional maupun dengan metode collaborative learning. Mahasiswa yang mengikuti kuliah dengan metode collaborative learning memiliki motivasi lebih tinggi dibandingkan mahasiswa yang mengikuti kuliah konvensional.

Korespondensi: herman.untad@gmail.com 
Kesimpulan: Collaborative learning lebih baik dalam meningkatkan motivasi belajar mahasiswa terhadap materi kuliah dengan topik Gizi Kesehatan Masyarakat.

KATA KUNCI: kuliah, kuliah konvensional, collaborative learning, motivasi belajar

\section{PENDAHULUAN}

Perkuliahan merupakan metode pembelajaran tertua dan paling banyak digunakan di universitas-universitas di dunia, meskipun metode-metode pengajaran yang lain sudah banyak dikembangkan. ${ }^{1}$ Metode perkuliahan ada dua yaitu metode perkuliahan konvensional dan tidak konvensional (interaktif).

Pada perkuliahan konvensional hanya dosen yang aktif terlibat dalam pembelajaran, sedangkan mahasiswa pasif. ${ }^{2,3}$ Sementara pada perkuliahan interaktif mahasiswa terlibat secara aktif selama kuliah. ${ }^{4}$ Perkuliahan konvensional merupakan kebalikan dari kuliah interaktif.

Dalam proses pembelajaran, seharusnya mengintegrasikan ranah kognitif, afektif, dan psikomotorik. Pembelajaran hendaknya memfokuskan pada proses mendidik dan tidak sekedar mentransfer pengetahuan begitu saja. Metode pembelajaran yang hanya meneruskan pengetahuan tidak memberikan peluang kepada mahasiswa berinteraksi dan bertransaksi antar mahasiswa $^{5}$. Hal ini menyebabkan mahasiswa kehilangan waktu untuk mengartikulasikan pengalaman belajar. Pada perkuliahan konvensional, pembelajaran kurang memberikan latihan berfikir kritis dan interaksi sosial hanya mendapatkan porsi waktu yang sangat sedikit karena pengajar hanya disibukkan dengan tugas rutinitas untuk segera "menuntaskan" kurikulum yang menjadi tanggung jawabnya. Dengan kata lain, cara-cara kerja sama atau kolaborasi untuk memberikan latihan berpikir kritis melalui pemecahan masalah hampir tidak dilakukan dalam situasi pembelajaran. Akibatnya, tidak dapat dipungkiri lagi bahwa pengembangan aspek-aspek kerja sama, menghargai pendapat, mengenali diri sendiri dan orang lain, dan sejenisnya terabaikan dalam proses pembelajaran.

Salah satu metode kuliah interaktif adalah metode collaborative learning. Pada metode ini mahasiswa tidak hanya sebagai pendengar yang pasif, tetapi ikut aktif terlibat dalam perkuliahan melalui diskusi dalam kelompok-kelompok kecil. Model diskusi kelompok kecil pada metode ini terarah sebagai usaha untuk mengaktifkan proses interaksi dan kerja sama antar mahasiswa.

Kerja sama antar mahasiswa di kelompok kecil yang dimaksud adalah proses yang dilakukan baik antar individu maupun antar kelompok, yang saling memperhatikan dan menghargai sesama anggota untuk mencapai tujuan bersama. ${ }^{6,7}$ Manfaat pembelajaran kolaboratif adalah, "Collaborative learning affords student enormous advantages not available from more traditional instruction because a group-whether it be the whole class or a learning group within the classcan accomplish meaningful learming and solve problems better than any individual can alone., Berdasarkan kutipan tersebut, pembelajaran kolaborasi menekankan pentingnya pengembangan belajar secara bermakna dan pemecahan masalah secara intelektual serta pengembangan aspek sosial.

Salah satu tipe perkuliahan metode collaborative learning adalah Student Team-Achievement Division (STAD). ${ }^{8}$ Tipe STAD terdiri dari sembilan langkah, yakni: 1) Sebelum mahasiswa berkumpul menurut kelompok STAD masing-masing, tutor menjelaskan ringkasan materi sekitar 10-15 menit; 2) Tutor mempersilahkan para mahasiswa berkumpul menurut kelompok STAD masing-masing; 3) Semua kelompok disuruh menyelesaikan tugas-tugas yang ada di Lembar Kegiatan Siswa (LKS) sampai tuntas untuk cakupan materi tertentu sesuai dengan alokasi waktu yang disediakan; 4) Masingmasing mahasiswa berdiskusi dan saling bertukar pendapat untuk memformulasikan jawaban; 5) Salah seorang anggota kelompok bertugas menulis jawaban yang telah disepakati bersama; 6) Tutor mengumpulkan laporan masing-masing anggota kelompok; 7) Setidaktidaknya setelah dua atau tiga LKS selesai dibahas, tutor memberikan kuis satu atau dua soal diambilkan dari LKS atau soal dibuat sendiri untuk alokasi waktu 10 menit; 8) Laporan mahasiswa dikoreksi, dikomentari, dinilai, dikembalikan pada pertemuan berikutnya, dan didiskusikan; dan 9) Hasil kuis dikoreksi dan dibuat daftar kemajuan yang dialami oleh mahasiswa dalam kuis tersebut. 
Berdasar wawancara dengan mahasiswa dan dosen pengampu dapat diperoleh informasi bahwa sebagian besar dosen masih menggunakan metode perkuliahan konvensional sehingga kurang memotivasi mahasiswa untuk belajar. Kurangnya motivasi belajar mahasiswa juga dapat diketahui pada keadaaan berikut ini: 1) pada proses pembelajaran ada sebagian mahasiswa yang tidak memperhatikan materi yang disampaikan oleh dosen, dan kurang memiliki kemauan untuk belajar yang terlihat seperti mengantuk, cerita dengan teman di samping bahkan ada yang bermain handphone; dan 2) masih kurangnya kemampuan mahasiswa untuk mengemukakan pendapat dan menjawab ketika dosen memberikan pertanyaan, mereka lebih suka menjawab secara bersama-sama ketika dosen memberikan pertanyaan sehingga menyebabkan mahasiswa kurang termotivasi dalam menempuh proses pembelajaran dalam kelas.

Berdasarkan hal-hal tersebut di atas, peneliti tertarik untuk mengetahui tingkat motivasi belajar mahasiswa yang menempuh kuliah dengan menggunakan metode collaborative learning dibandingkan dengan kuliah dengan metode konvensional. Tujuan penelitian ini adalah membandingkan tingkat motivasi belajar mahasiswa pada kuliah konvensional dengan collaborative learning.

\section{METODE}

Penelitian ini adalah studi kuantitatif dengan metode eksperimental rancangan post-test only with control group. Penelitian ini memberikan perlakuan berbeda kepada kelompok intervensi dan kelompok kontrol.

Pada kelompok intervensi dilakukan pengajaran dengan metode collaborative learning, sedangkan kelompok kontrol dilakukan dengan metode konvensional. Pengelompokan dilakukan dengan cara undian. Pengukuran motivasi belajar pada penelitian ini menggunakan versi terjemahan Motivated Strategies for Learning Questionneire (MSLQ) yang dikembangkan oleh National Center for Research to Improve Postsecondary Teaching Learning, Universitas Michigan. ${ }^{9}$
Penelitian dilakukan pada topik perkuliahan gizi kesehatan masyarakat di PSIKM UNTAD Palu. Hal ini didasarkan pada pertimbangan kesiapan dosen pengampu dan waktu. Metode pengambilan sampel pada penelitian ini adalah total sampling. Sebanyak 89 mahasiswa semester 2 menjadi sampel pada penelitian ini.

Mahasiswa kemudian ditempatkan secara acak dalam dua kelompok, yakni kelompok mahasiswa yang menempuh kuliah konvensional dan kelompok mahasiswa yang menempuh kuliah dengan metode collaborative learning. Dari 89 sampel pada penelitian ini, hanya 66 mahasiswa yang mengikuti penelitian sampai dengan selesai. Jumlah mahasiswa kelompok perlakuan sebanyak 28 orang dan mahasiswa kelompok kontrol sebanyak 38 orang.

Staf pengajar yang dilibatkan dalam penelitian berdasarkan minat, ketersediaan dan kemampuan staf. Staf pengajar yang dipilih sudah mempunyai pengalaman mengajar kurang lebih 20 tahun dan mempunyai minat untuk terlibat dalam proses penelitian pendidikan kedokteran.

Sebelum penelitian dilakukan, peneliti memberikan proposal penelitian kepada staf pengajar tersebut, hal ini dimaksudkan agar staf pengajar paham betul apa maksud dan tujuan dari penelitian. Kemudian peneliti melakukan pelatihan kepada staf pengajar tersebut dengan tujuan untuk menyamakan persepsi tentang cara mengajar dengan menggunakan metode collaborative learning, yaitu metode pengajaran yang melibatkan peran aktif mahasiswa dari berbagai latar belakang untuk bekerjasama dalam kelompok kecil dalam rangka mencapai tujuan pembelajaran secara umum. ${ }^{10}$ Adapun model sistem pembelajaran collaborative learning adalah sebagai berikut: 


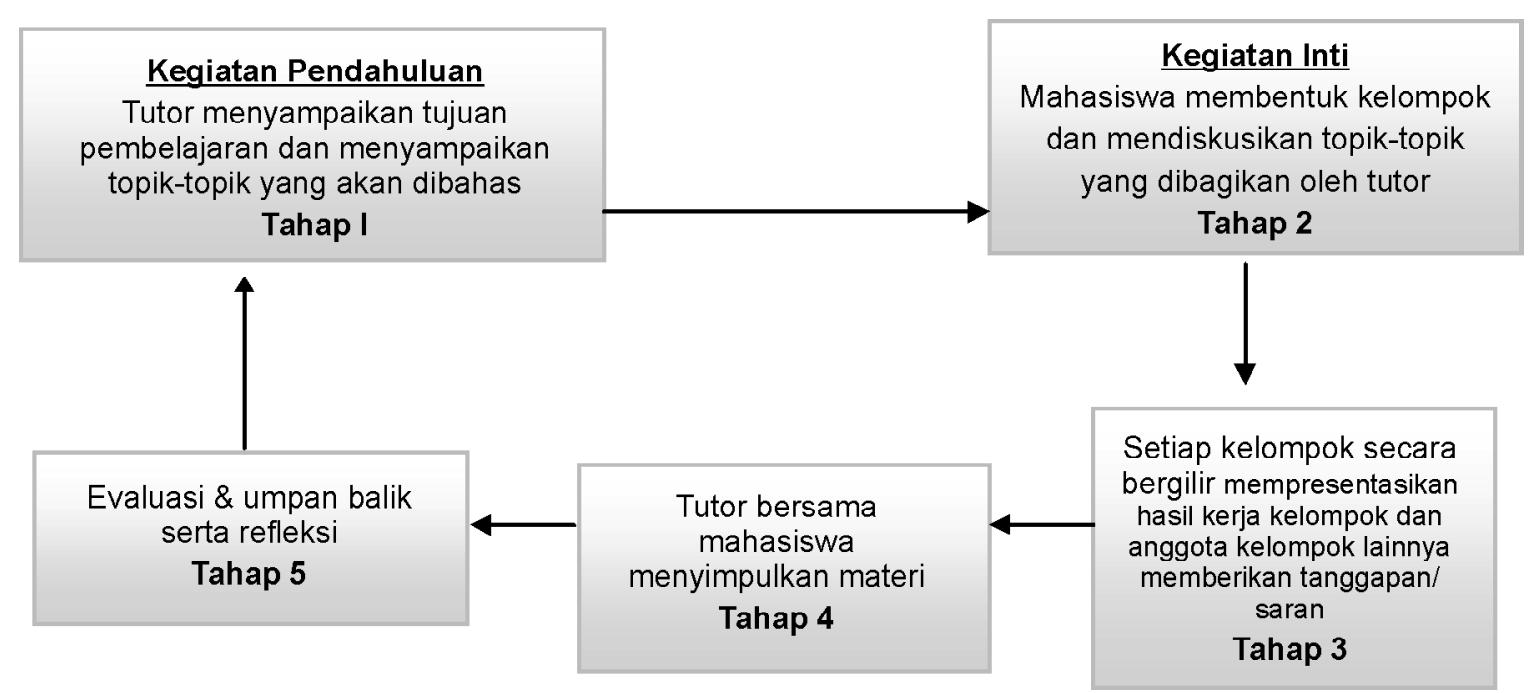

Gambar 1. Model sistem pembelajaran kolaboratif ${ }^{11}$

Model sistem pembelajaran kolaboratif sebagaimana terlihat pada gambar di atas mencakup lima tahap kegiatan yang harus dilaksanakan selama dalam proses pembelajaran berlangsung. Tahap pertama merupakan kegiatan pendahuluan yang ditujukan kepada tutor dan mahasiswa agar memiliki persepsi yang sama sebelum pembelajaran dilaksanakan. Oleh sebab itu, pada tahap ini tutor yang terlibat dalam proses pembelajaran penting menyampaikan tujuan pembelajaran, topik-topik apa yang akan dibahas, serta menjelaskan secara singkat kegiatan yang akan dilakukan, serta hasil yang akan diharapkan. Demikian pula perlu disampaikan pendekatan, model, dan metode yang diterapkan dalam kegiatan pembelajaran yang berlangsung selama 2 x 45 menit. Agar semua ini tercapai, tutor perlu menguasai karakteristik dari setiap mahasiswa yang mengikuti kegiatan pembelajaran agar terjadi jalinan yang akrab, saling bekerjasama, saling sharing pendapat, sehingga dengan mudah tujuan pembelajaran yang diharapkan dapat terwujud sesuai dengan harapan.

Sebelum dilakukan penelitian diadakan pertemuan dengan mahasiswa. Pertemuan ini bertujuan untuk meminta ijin dan kesediaan menjadi responden penelitian. Pada kesempatan ini mahasiswa dijelaskan tentang prosedur pelaksanaan penelitian. Mahasiswa diberi kebebasan jika tidak bersedia mengikuti penelitian.

Selama penelitian, masing-masing kelompok mendapatkan materi kuliah yang sama. Dalam satu hari dilakukan satu kali kuliah konvensional dan hari berikutnya satu kali kuliah dengan metode collaborative learning dengan materi dan pengajar yang sama, perbedaan hanya terletak pada metode mengajar. Setiap akhir sesi perkuliahan, masing-masing mahasiswa mendapatkan kuesioner motivasi yang langsung diisi oleh mahasiswa bersangkutan. Lembar kuesioner motivasi tidak diberi nama dan hanya diberi nomor induk mahasiswa.

Setelah skor kuesioner motivasi terkumpul, selanjutnya dilakukan analisis statistik untuk diambil kesimpulan. Setelah dilakukan uji normalitas data dengan uji Kolmogorov-Smirnov diketahui bahwa distribusi data tidak normal sehingga digunakan uji Mann-Whitney.

\section{HASIL DAN PEMBAHASAN}

Motivasi belajar mahasiswa diukur dengan Motivated Strategies For Learning Questionnaire (MSLQ) yang dilakukan setelah proses belajar, baik pada metode konvensional maupun pada metode collaborative leaming. Tabel 1 berikut menunjukkan nilai rerata motivasi belajar mahasiswa. 
Tabel 1. Rerata motivasi belajar mahasiswa

\begin{tabular}{lcc}
\multirow{2}{*}{\multicolumn{1}{c}{ Metode }} & \multicolumn{2}{c}{ Motivasi Belajar } \\
\cline { 2 - 3 } & Rerata & SD \\
Konvensional & 81,18 & 21,116 \\
Collaborative & 107,32 & 10,629 \\
\hline
\end{tabular}

$\mathrm{SD}=$ Standar Deviasi

Tabel 1 menunjukkan terdapat perbedaan bermakna nilai rerata motivasi belajar mahasiswa. Rerata mahasiswa yang menempuh kuliah dengan metode konvensional 81,18 sedangkan yang menempuh kuliah dengan metode collaborative learning 107,32.

Perbandingan rerata skor motivasi belajar antara motivasi belajar mahasiswa yang menempuh kuliah dengan metode konvensional dengan kuliah dengan metode collaborative learning menunjukkan perbedaan bermakna. Ada tiga komponen motivasi yang diteliti pada penelitian ini yaitu intrinsic goal orientation, task value dan self efficacy for learning and performance. Intrinsic goal orientation adalah alasan menempuh proses pembelajaran karena tertantang, rasa ingin tahu, ingin bisa atau ahli, pemenuhan standar pribadi dan pemberdayaan diri. Task value adalah persepsi mahasiswa tentang materi pembelajaran terkait dengan ketertarikan, kepentingan, dan kegunaan materi tersebut. Self efficacy adalah suatu penilaian terhadap kemampuan atau kompetensi diri untuk mencapai sukses dalam suatu tugas. ${ }^{12,13}$

Tabel 2. Rerata komponen motivasi belajar mahasiswa

\begin{tabular}{lccc}
\multirow{2}{*}{ Metode } & \multicolumn{3}{c}{ Motivasi Belajar } \\
\cline { 2 - 4 } & IGO & TV & SE \\
\hline Konvensional & 16,87 & 30,24 & 33,97 \\
Collaborative & 24,68 & 37,25 & 45,39 \\
\hline
\end{tabular}

Tabel 2 menunjukkan terdapat perbedaan bermakna dari ketiga komponen motivasi belajar mahasiswa yang mengikuti kuliah dengan metode konvensional dengan metode collaborative learning. Rerata komponen IGO (intrinsic goal orientation) pada metode konvensional adalah 16,87 dan pada collaborative 24,68, untuk TV (task value) pada metode konvensional 30,24 dan pada collaborative 37,25, sedangkan pada SE (self efficacy for learning and performance) pada metode konvensional reratanya adalah 33,97 dan pada collaborative 45,39.

Hasil uji rerata pada ketiga komponen motivasi yakni intrinsic goal orientation, task value dan self efficacy for learning and performance menunjukkan bahwa terdapat perbedaan bermakna antara metode konvensional dan metode collaborative learning. Hasil Penelitian ini sama dengan hasil penelitian-penelitian terdahulu, misalnya penelitian terhadap mahasiswa yang menempuh kuliah fisiologi interaktif dengan alat personal response system. Pada penelitian tersebut diketahui sebanyak $83 \%$ mahasiswa yang mengikuti kuliah interaktif merasa termotivasi untuk berfikir dibandingkan dengan mahasiswa yang menempuh kuliah yang tidak interaktif. ${ }^{14} \mathrm{Hal}$ serupa juga dilaporkan pada penelitian terhadap mahasiswa teknik mesin yang mendapatkan kuliah interaktif pada topik pendahuluan teknik mesin. Mahasiswa yang mendapat perkuliahan interaktif merasa lebih termotivasi untuk mendatangi perkuliahan dibandingkan dengan mahasiswa yang menempuh kuliah konvensional. ${ }^{3}$ Penelitian lain melaporkan bahwa motivasi pada mahasiswa yang mengikuti kuliah menggunakan prinsipprinsip Gagne lebih tinggi dari pada yang mengikuti kuliah tradisional, namun perbedaannya tidak bermakna secara statistik. ${ }^{15}$ Penelitian lain mengenai partisipasi mahasiswa juga menunjukkan hal yang sama. Pada mahasiswa yang berpartisipasi dalam kelompok belajar bersama lebih termotivasi secara instrinsik dibanding mahasiswa yang diajar secara individu. ${ }^{16} \mathrm{Hal}$ ini sesuai dengan pendapat para ahli yang menyatakan bahwa salah satu dampak positif pembelajaran interaktif adalah dapat meningkatkan motivasi intrinsik. ${ }^{17}$

Beberapa penelitian menunjukkan bahwa tidak ada perbedaan yang bermakna antara kuliah konvensional dan interaktif. Hal tersebut karena pengajar adalah seorang ahli di bidangnya, interaski langsung dengan seorang ahli akan meningkatkan perhatian mahasiswa. ${ }^{18}$ Selain itu, fasilitasi belajar oleh seorang ahli akan meningkatkan intrinsic goal orientation, task value dan self efficacy mahasiswa. ${ }^{19}$ Menurut expectancy value theory, task value bersama dengan self efficacy dan harapan mahasiswa (bagian dari intrinsic goal orientation) akan mempengaruhi perhatian dan upaya mahasiswa dalam mencapai suatu performa akademik, termasuk pengetahuan. ${ }^{19}$ Perhatian dan upaya mahasiswa tersebut harus ditingkatkan dan 
difasilitasi melalui suatu metode pengajaran. Tujuannya agar mahasiswa mampu mencapai suatu performa akademik dan pengetahuan yang baik. Berdasarkan teori ini, tidak adanya hubungan yang bermakna antara perubahan motivasi, self efficacy dan intrinsic goal orientation dengan perubahan pengetahuan karena belum optimalnya metode pengajaran dan fasilitasi yang digunakan untuk meningkatkan perhatian mahasiswa.

Analisis bivariat motivasi belajar menggunakan uji Mannwhitey. Hasil perbandingan rerata motivasi belajar mahasiswa menunjukkan ada perbedaan bermakna motivasi belajar mahasiswa setelah menempuh proses belajar dengan metode konvensional dan metode collaborative learning yaitu metode konvensional mempunyai rerata skor akhir 22,95 dan jumlah rank akhirnya 872 , kemudian metode collaborative learning mempunyai rerata skor akhir 47,82 dan jumlah rank akhirnya 1339.

Berdasarkan hasil analisis perbandingan hasil post-test dengan menggunakan uji Mann-Whitney diperoleh adanya perbedaan motivasi belajar mahasiswa yang signifikan antara metode pembelajaran collaborative dengan metode konvensional. Metode collaborative learning meningkatkan motivasi belajar mahasiswa lebih tinggi.

Hasil pada penelitian ini sudah sesuai dengan beberapa penelitian mengenai kuliah interaktif terdahulu yang menunjukkan bahwa penerapan pembelajaran metode collaborative learning berpengaruh positif terhadap peningkatan motivasi belajar mahasiswa di PSIKM UNTAD Palu. Sehingga metode collaborative learning bisa menjadi salah satu alternatif metode pembelajaran interaktif di PSIKM kedepan.

Pendekatan pembelajaran interaktif menyatakan bahwa belajar adalah suatu proses sosial yang terjadi melalui komunikasi antara pengajar dengan mahasiswa dan antar sesama mahasiswa. ${ }^{20}$ Mahasiswa secara aktif mengkonstruksi pengetahuannya dengan cara memformulasikan ide-ide atau gagasan-gagasan kedalam ungkapanungkapan dan ide yang dibangun melalui reaksi dan respon dari pihak lain. ${ }^{20,21}$ Dengan ungkapan lain, mahasiswa bukan hanya aktif tetapi juga interaktif. Prosesproses pembelajaran yang lebih mengaktifkan mahasiswa ini berorientasi pada mahasiswa atau dikenal dengan learner-centered orientation. Interaksi timbal balik bukan hanya terjadi antara mahasiswa dengan pengajar, tetapi juga antara mahasiswa (transaksional). Pola interaksi ini akan lebih mengembangkan proses-proses sosial yang lebih tinggi, sehingga akan semakin memupuk jiwa keberanian mengemukakan pendapat, pandangan, pikiran, perasaan dan pada gilirannya akan menumbuhkan jiwa kerja sama atau kolaborasi.

Pembelajaran collaborative learning bisa menjadi salah satu alternatif pembelajaran yang dapat diaplikasikan di perguruan tinggi, terutama di PSIKM UNTAD. Caracara pembelajaran collaborative learning ini lebih menggerakkan atau mendorong secara aktif dan interaktif para mahasiswa untuk saling bekerja sama untuk menyelesaikan tugas-tugas akademik di kelas. Pembelajaran collaborative learning lebih memandang proses pembelajaran sebagai learner-centered dan bukan teachercentered. Pengetahuan dipandang sebagai suatu konstruk sosial, difasilitasi melalui interaksi antar kelompok sebaya, evaluasi dan kooperasi. Oleh sebab itu, peran pengajar berubah dari sebagai penyampai informasi (transferring knowledge), "the sage on the stage" menjadi seorang fasilitator. Dalam pembelajaran interaktif akan terjadi proses konstruksi pengetahuan di dalam diri mahasiswa, "the guide in the side". ${ }^{22}$ Kunci untuk pembelajaran bermutu adalah memaksimalkan partisipasi mahasiswa di dalam berinteraksi. Didalam proses interaksi maka para mahasiswa secara bersamasama akan berfikir, bertukarpikiran, atau beradu pendapat. ${ }^{9}$

\section{KESIMPULAN}

Hasil penelitian menunjukkan terdapat perbedaan motivasi mahasiswa yang bermakna antara mahasiswa yang mengikuti kuliah menggunakan metode konvensional dan kuliah dengan metode collaborative learning. Motivasi belajar mahasiwa lebih tinggi ketika mengikuti kuliah dengan metode collaborative learning dari pada mahasiswa yang mengikuti kuliah metode konvensional. Ini berarti pembelajaran metode collaborative learning memiliki pengaruh positif terhadap peningkatan motivasi belajar mahasiswa. Oleh karena itu, metode pembelajaran collaborative learning dapat menjadi salah satu alternatif metode kuliah interaktif di institusi pendidikan. Penelitian lanjutan disarankan dengan menambah variabel penelitian, populasi yang 
lebih banyak, dan waktu penelitian yang lebih lama sehingga diperoleh hasil yang lebih baik.

\section{UCAPAN TERIMAKASIH}

Penulis mengucapkan terima kasih kepada Prof. dr. Harsono, Sp.S (K) dan dr. Gandes Retno Rahayu, M.Med.Ed, Ph.D yang telah memberikan masukan pada penelitian ini.

\section{DAFTAR PUSTAKA}

1. McKeachi.W.J. \& Syinicki. M. McKeachie's teaching tips: Strategies, research, and theory for college and university teachers $\left(12^{\text {th }}\right.$ ed.). Boston: Houghton Mifflin; 2006.

2. Newble, D. \& Cannon, R. A Handbook For Medical Teachers. $4^{\text {th }}$ ed. Kluwer Academic Publishers; 2001.

3. Dijk, L.A.V. \& Jochems, W.M.G. Changing A Traditional Lecturing Approach into An Interactive Approach : Effects of Interrupting the Monologue in Lecture. Int.J.Enging Ed. 2002;18(3):275-85.

4. Knight, J.K. \& Wood, W.B. Teaching More by Lecturing Less. Cell Biol Educ. Winter. 2005;4(4): 298-310.

5. Hiltz, S.R. Collaborative Learning in Asynchronous Learning Network: Building learning communitie. New Jersey Institute of Technology; 1998.

6. Setyosari, P. Pembelajaran Kolaborasi; Landasan untuk mengembangkan keterampilan sosial, rasa saling menghargai dan tanggung jawab (desertasi). Malang (Indonesia): Universitas Negeri Malang. 2009.

7. Tinzmann, M.B., Jones, B.F., Fennimore, T.F., Bakker, J. Fine, C., \& Pierce, J., What Is The Collaborative Class Room? NCREL, Oak Brook; 1990.

8. Slavin, R. E. Cooperative Learning. Second edition. Boston: Allyn and Bacon; 1995.

9. Suhoyo, Y. Perbandingan Efektifitas antara Computer-Base Learning (CBL) dan Kuliah Sebagai Metode Pengajaran Prinsip Dasar Bioetika pada Mahasiswa Baru [tesis] Yogyakarta (Indonesia). Universitas Gadjah Mada; 2008.

10. Harsono, Dwiyanto, D., pembelajaran berpusat mahasiswa, pusat pengembangan pendidikan. Universitas Gadjah Mada Yogyakarta; 2005.

11. Husain, R. Pengembangan Model Pembelajaran Kolaboratif Dalam meningkatkan Hasil belajar Warga Belajar Paket C (Studi di SKB Kota Gorontalo) [desetasi]. Gorontalo (Indonesia): Universitas Pendidikan Indonesia; 2012.

12. Pintrich, P.R.,Smith, D.A.F.,Garcia, T. \& McKacachie, W.J. A Manual for tha use of the Motivated Strategies for Learning Questionnaire (MSLQ). University of Michigan, National Center for Researsch to Improve Postsecondary Teaching and Learning; 1991.

13. Marcou, A. \& Phlippou, G. Motivational beliefs, seltregulated learning and mathematical problem solving. In chick, H.L.\&Vincent, J.L.(eds.). Proceeding of the 29th Conference of the International group for the psycology of Matematic Education (dokumen on the internet). Melbourne: PME; 2005;3: 297-304. Available from: www.emis.de/proceedings /PME29/ PME29RRPapers/PME29Vol3MarcouPhilppou.pdf

14. Gauci, S.A., Dantas, A.M., Williams, D.A., \& Kemm, R.E. Pomoting student-centered active learning in lecture with a personal response syste. Adv Physiol. Education. 2009;31:41-4.

15. Ichsan, B. (2009) Perbandingan Efektifitas antara Kuliah Menggunakan Prinsip-Prinsip Gagne dan Kuliah konvensional pada Mahasiswa Fakultas Kedokteran Universitas Muhammadiyah [tesis] Surakarta (Indonesia). Universitas Gadjah Mada; 2008.

16. Slavin, R. E. Coopertive learning; Where Behavior and Humanistic Approaches to Classroom Motivation Meet Source. The Elementary School. The University of Chicago Press: 1978;88(1):29-37.

17. Johnson, D. W,. Johnson, R.T., \& Stanne. M.B Jacobs,. Cooperative Learning Method: A MetaAnalysis. University of Minneasota 60 Peik Hall 159 pillsbury Drive, S.E. Minnesoapolis, Minneasota 55455; 2000.

18. Amin, Z. \& Eng, K.H. Basic in Medical Education. Singapore : Word Scientific Publishing Co. Pte.Ltd; 2003.

29. Driscall, M.P. The motivation to learn. Psychology of learning for instruction. Boston: Allyn and Bacon, 1994; 294-326.

20. Bouton, C. \& Garth, R.Y. 1993 Learning in Groups. San Fransisco: Jossey-Bass, Inc; 1993

21. Alavi, M. "Computer-mediated collaborative learning: An empirical evaluation”. MIS Querterly. 1994; 150174.

22. Hiltz, S.R. \& Turoff, M. The Network Nation: Human communicsation via computer._Revised edition, Cambridge MA: MIT Press; 1993. 